\title{
INVESTMENT DECISION IN MICRO, SMALL AND MEDIUM ENTERPRISES IN INDONESIA *
}

\author{
Siti Aisyah Tri Rahayu \\ Faculty of Economics, Sebelas Maret University \\ Jalan Ir. Sutami No. 36 A Kentingan Surakarta 57126, Telp \& Facsimile: 0271-647481, 0271-638143 \\ E-mail: aisyahrahayu@yahoo.com
}

Diterima 30 November 2012/ Disetujui 4 Mei 2013

\begin{abstract}
The purpose of this study are: First, to analyze is there any significant influence among debt ratio, internal capital, cash flow, inflation expectations and the expectations of rupiah exchange rate against the decisions of businessmen in the real sector to invest or not to invest; Second, to analyze the impact of the variables perception mortgage interest rates, perceptions of bank regulation, internal capital and cash flow on debt ratio of the real sector (leverage). Investment decision model is estimated using logit models. The results of regression estimates the overall good for business and risk analysis for financial risk shows that almost all explanatory variables in the equation are statistically significant. There are three variables have a positive influence on the investment decisions taken by the businesses i.e. the debt ratio, cash flow and exchange rate expectations. While the alternative investments and inflation expectations are not significant statistically.
\end{abstract}

Keywords: investment decision, business risks, financial risk, debt ratio JEL: E22, M21

\begin{abstract}
Abstrak: Tujuan penelitian ini: pertama, untuk menganalisis apakah ada pengaruh yang signifikan antara rasio utang, kas internal, arus kas, ekspektasi inflasi dan ekspektasi nilai tukar rupiah terhadap keputusan pengusaha di sektor riil untuk berinvestasi atau tidak berinvestasi; kedua untuk menganalisis pengaruh variabel persepsi suku bunga kredit, persepsi bank regulasi, kas internal dan arus kas terhadap rasio utang usaha di sektor riil. Model keputusan investasi diperkirakan menggunakan model logit. Hasil regresi memperkirakan secara keseluruhan baik untuk analisis bisnis dan risiko untuk menunjukkan risiko keuangan bahwa hampir semua variabel penjelas dalam persamaan yang signifikan secara statistik. Ada tiga variabel memiliki pengaruh positif terhadap keputusan investasi yang diambil oleh perusahaan yaitu rasio utang, arus kas dan ekspektasi nilai tukar. Sedangkan alternatif investasi dan ekspektasi inflasi tidak signifikan secara statistik.
\end{abstract}

Kata kunci: keputusan investasi, risiko bisnis, risiko keuangan, rasio utang

JEL : E22, M21

\section{INTRODUCTION}

Indonesia's economy is currently facing a very crucial issue. Problems can be seen from the main macroeconomic indications, that is, slow

\footnotetext{
* This paper has been presented in 8th Annual Asia Pacific Economics Association Conference in Nanyang Technological University, Singapore, 27-28 July 2012.
}

economic growth in Indonesia, although the general condition of the domestic economy is quite stable. Slowing economic growth during the recent years indicated are related to the impact of financial crisis that occurred mid1997.

The monetary crisis that began in mid-1997 caused a crisis in the financial and banking sector, which is characterized by the decline of 
the rupiah against the U.S. dollar and the deteriorating banks performance and result in liquidated banks that are predicted to have been unable to perform its functions properly. Declining bank performance led to another more serious problem in financial intermediation of the banking sector to the real sector. As a result, bank intermediary function can not be directly working properly. Until April 2007 from the third party funds reached $\mathrm{Rp} 1299.772$ billion, only $\operatorname{Rp} 812.860$ billion which could be channeled into the real sector. This means that the lending ratio (LDR) was only 62.54 percent. This means that banking institutions still have excess funds of about Rp 486.912 billion.

Impact of monetary crisis in mid 1997 is still felt today. Based on data from the World of Business Activity Survey (SKDU), published by Bank Indonesia, in the first quarter of 2007 the company indicated a slight contraction in business activity, as reflected in the Net Weighted Balance (SBT) of $-0.24 \%$.

The government has established a variety of stimuli through the packages and infrastructure investment policies in order to accelerate economic recovery at the beginning of 2006 and the package of financial policy at the beginning of the second semester of 2006 . However, these policy packages have not yet realized, and show a real impact in the real sector. Slow growth of the real sector impact on economic sustainability.

Green, et al. (2004) found that many companies still face obstacles in obtaining access to financing their business. In a survey on investment climate and productivity by the ADB and the World Bank, with 700 large and medium enterprises in Indonesia, about 39 percent of companies face obstacles in access to finance and 49 percent of them face high costs in financing its production process. Furthermore, Green (2004) states, the largest proportion of the loans are for consumption purposes, while relatively smaller proportion for investment and working capital. This condition indicates that credit is channeled to the real sector with the purpose of investment and production still has many obstacles.

More recently, Stiglitz (2003) pioneered the emergence of a new paradigm of economic monetary. Stiglitz argues that the financial institutions, banks and capital markets are the "brains" of the economy. These agencies collect and process information dissemination to the scarcity of capital to be allocated. The good performance of financial institutions showed the good performance of the economy as a whole. Furthermore, Stiglitz emphasized the important role of financial institutions especially in developing countries where capital is scarce and therefore an efficient allocation of capital is very important.

In developing countries, the majority of capital is equity capital and of bank loans (as well as in developed countries). This is because the company is very difficult to find funds from the stock, primarily due to information asymmetry. This asymmetry of information have devastating effects on the stock market, so as not to create the equilibrium prices (zero price), thus no shares were sold (zero sale). There is a rill of market failure in the stock market information. Previous studies by Stiglitz and Weiss (1981) found that information asymmetry can disrupt financial market transactions. Stiglitz (1988), Leland and Pyle (1977), and Diamond (1984) suggested a similar case regarding the existence of information asymmetry that can answer the frictions in financial markets. Mishkin (2001: 182) emphasizes the central role of banks as a source of external financing for the business sector, even in developed countries, which are summarized in eight financial puzzles, namely: (1) share of external financing sources are not the most important in the finance business, (2) creating a marketable debt and equity securities are not in a major way in which the company finance its operations, (3) indirect financing, which include the financial activities of intermediaries, is more important than direct finance, in which businesses obtain funds directly from lenders in financial markets, (3) the bank is the source of the most important external funds to finance the business, (5) financial system is in a sector of the economy is heavily loaded with regulations, (6) only the large and established companies that have access to the securities market weeks to finance their activities, (7) guarantees is an offer. The good performance of financial insti- 
tutions showed the good performance of the economy as a whole view of debt contracts for both households and for businesses, (8) debt contracts in particular is a highly complex legal documents that place substantial restrictions on the behavior of borrowers.

According to Stieglitz (2003), the Bank is not only a source of funding but also the determinants of business cycle the economy as a whole. In the period 2001-2004, the flow of credit from the banking sector contributed an average of $77 \%$ of the total financing of financial institutions (Alamsyah, 2004). As a result, the condition of the banking system has a very strong correlation with economic activity in Indonesia.

Several empirical studies on the determinants of investment companies produce different findings. Seminal contribution of Myers and Majluf (1984) showed that internal funding (which does not cause costs and information problems) are generally preferred over external financing. Recent studies (Hoshi, Kashyap and Scharfstein, 1991) show that financial factors such as availability of internal funds (net worth) affect corporate investment, reflecting the presence of obstacles for companies in obtaining external funding.

Meanwhile, greater access for large business groups to external financing is confirmed by a qualitative survey by Ang, Fatemi, Tourani-Rad (1997) against 40 major trading companies in Indonesia. They suggest that despite internal funding as a trusted source of funding cheaper than external financing, the study found no significant evidence on the issue of information asymmetry between large companies and banks and therefore they prefer to bank. So, it is not too surprising if it is found that a very strong relationship between large companies and banks. Interview conducted by Pinto and Glen (1994) suggest that the choice of the company regarding the source of funds is more influenced by the amount, than the cost of funds, where they can access to expand their market share. The Company stated that they were compelled to listing on the stock market in order to gain access to cheaper foreign sources.

Imperfect information conditions is also an important determinant of leverage investment decision [(Schiantarelli and Sembenelli, 1995, and Bond and Meghir, 1994) in Goeltom and the Great (2000). The main reason is that leverage and agency costs associated with external finance is also an encouragement to the negative effects of corporate investment. Literature studies show that high leverage exacerbated agency problems (Jansen and Meckling, 1976 and Myers, 1977). Myers (1977), as an example, deals with debt, which has a positive NPV projects will not be implemented if the capital needed to finance the project is not provided by the shareholders.

The fact that there are still obstacles in the real sector to invest and increase productivity associated with many factors. On the one hand, business prospect still considered not to have a better prospect, made it difficult to gain access to financing investment. On the other hand, the manager's decision affects the activities of the company to invest. Preferences of managers in making investment and financing decisions are influenced by many factors such as the goal of managers in managing the company, the choice of sources of funds, leverage the company's corporate and external factors of macroeconomic conditions.

Investment refers to the commitment of resources for fixed assets used for production. Characteristic of the investment decision is that the purchase and use of capital goods, including costs and revenues are spread over several periods. Use of capital by company involves a significant element of time into the production process, for which create services not be useful at the moment of capital goods produced or sold, but must be planned over several periods. Therefore, the time value of money should be taken into account to properly evaluate investment alternatives. Furthermore, the risk in investment decision-making is greater than the rest of the company. All decisions require predictions of the future, but in the case of investment goods should always be extended to forecast the next period where there is uncertainty. The factors that affect managers in making decisions on how much debt the company's capital structure used is important. This is important because it determines the cost of capital, which is widely used as a criterion in 
optimal investment decisions.

Behavior of managers in utilizing funding sources to finance investment is an important issue from the viewpoint of the theory and practice. Determination of funding sources to finance the investment from the viewpoint of practice involving the interests of the owners, creditors, potential investors and corporate managers. Funding relationship with the investment decision-making from the viewpoint of the theory is still being debated in the finance literature. There are two issues being debated in the financial theory to explain the relationship. First, whether there is interaction between investment and leverage decisions. Second, differences in predictions about the direction and shape of the relationship of funding decisions (in selecting internal and external capital) and investment decisions are also related to the level of leverage.

Pecking order theory of capital or a hierarchy of funding based on the assumption that the "information asymmetry" in the market caused the cost of external capital more costly (Myers, 1984; and Myers and Majluf, 1984). Therefore managers prefer to use internal capital as the main funding source, when external capital is needed, they will choose a lower external capital risk, capital debt, while issuing new equity is the last sequence of pecking order capital. The concept of information asymmetry is adopted from Akerlof (1970). Myers and Majluf (1984) developed it in the context of determining the order of the funding that the information asymmetry occurs when the creditor can not distinguish "good borrower" and "bad borrowers" in the market risk premium that lenders charge the same for both. As a result, borrowers who either bear a higher risk premium, so they tend to reduce investment even though there is investments that provide a net present value (NPV) is positive if it is not enough available internal capital investment, resulting in less (under-investment) (Hermeindito, 2004).

Information asymmetry is also an assumption in agency theory of free cash flow that the behavior of managers in the use of internal capital difficult to control by the owner or outside investors (Jensen, 1986). Therefore, the owners sought to control the behavior of managers. Management efforts to control the owner, hereinafter referred to as "management control." Argument Jensen refers to the study of Murphy (1985) empirically found that growth was positively related to the levels of management compensation. This encourages managers to take advantage of internal capital investment company or to enlarge the company's growth, although there was no positive NPV investment projects resulting in over-investment.

Pecking order theory and free cash flow theory has a different explanation of why managers prefer internal capital rather than debt to finance capital investment. The difference lies in whether the assumption of "information asymmetry" or "management control" policies in explaining the phenomena that occur. Fazzari, Hubbard, and Petersen (1988) supports the argument Myers and Majluf (1984) that differences in information asymmetry in the marketplace have led to companies facing external financing constraints higher than other companies. Companies are experiencing the problem of information asymmetry is referred to as a company with high financial constraint (HFC), while the company is not experiencing the problem of information asymmetry is called a company with lower financing constraints (LFC). Furthermore, Fazzari, Hubbard, and Petersen (1988) using the dividend payout ratio as a proxy indicator of information asymmetry. High financial constraint's companies are experiencing difficulty in obtaining debt capital will rely more on internal capital rather than debt capital. Assuming other things constant, higher internal capital held in a company the lower the dividend payout ratio. Therefore, the investment company to be more sensitive to high financial constraint companies internal capital than the mortgage company.

Conversely, companies with low financial constraints to obtain external capital debt makes the company more flexibility in maintaining or increasing dividend payments. Thus, an investment firm with lower financing constraints become more sensitive to debt capital than firms with high financing constraints.

Free cash flow theory has the opposite explanation that financing constraints are more 
internal than external. Dividends and debt is a tool for owners to control the behavior of managers in the use of internal capital to finance investment. Companies with high internal capital needs to be controlled through a high dividend payout ratio.

Lower financing constraints in terms of agency theory Free Cash Flow is not caused by information asymmetry in the capital market but rather by the agency problems in internal capital or be more specific in terms of free cash flow. Firms with lower financing constraints are considered to have high internal capital so that if not controlled through increasing dividend payments, managers will utilize internal capital for investment. Therefore, owners perform management control through dividends. In contrast, firms with high financing constraints are considered to have a low internal capital so there is no incentive for owners internal capital controls the company through increased dividends. In this case the owner will use debt as a substitute dividend policy to control management in making funding decisions and investment decisions.

Empirical research on the effect of internal capital for investment revealed inconsistent results. Fazzari, Hubbard, and Petersen (1988) and Carpenter (1994) proved that investment firms with high financing constraints are more sensitive to internal capital than firms with lower financing constraints as predicted by the pecking order theory. Empirical studies by Griner and Gordon (1995) also support the pecking order theory rather than the theory of free cash flow. In another study, Kaplan and Zingales (1997) and Cleary (1999) found that investment with low financial constraints are more sensitive to internal capital funding constraints rather than higher. Research conducted by Vogt (1994) and Degryse and De Jong (2001) demonstrate empirically that the pecking order theory applies to small companies and the free cash flow theory applies to big companies. The results are inconsistent require further study to clarify the theory proving conceptually and empirically. Empirical studies of the impact of debt capital investment has not been a lot done. Carpenter (1994) examined the impact of debt on investment capital and find that the effect of debt-to-capital investments in companies with high financial constraints greater than firms with lower financing constraints.

The selection of funding sources does not only affect investment but also affect the leverage. Leverage decreases when firms use internal capital, and increases when firms use debt to finance capital investment. Empirical studies that have been done show that the negative effect on the profitability of leverage (Baskin, 1989; Chang and Rhee, 1990; Wald, 1999).

The problem is complex because of the increase in debt reflects the increased financial risk (increase in capital costs), thereby reducing alternative investment opportunities that provide positive NPV that can be realized by the company. Thus, leverage affect actual investment company. Several empirical studies investigating the effect of leverage on investment provide different results. Several empirical studies find that the leverage impact negatively on investment (Bond and Meghir, 1994a; Lang, Ofek, and Stulz, 1996;, and Cleary, 1999), whereas Kaaro (2002) find that leverage affects firm value in the form of a nonlinear relationship.

Companies make funding decisions to finance the production process by considering the factors that will determine the company's capital structure, namely (Koutsoyiannis, 1982: 400):

(1) The company's goal. If the manager has the goal of maximizing shareholder wealth then the optimal capital structure is to maximize the company's market value to shareholders. If the manager has the goal of securing a job, managers feel threatened if the ratio of debt / capital of the company in the long term deviates from the average ratio of debt / equity industry. (2) availability of internal funds: revenue growth rate. (3) Most managers prefer internal financing over external financing. The main determinant of internal funding is earnings growth of the company. The higher level of corporate earnings growth, enabling management to gain more retained earning, so that external funding is not so necessary. (4) availability of internal funds. Amount of internal funding is not only dependent on the growth of total income but also of the proportion of income that can be 
retained. (5) The degree of concentration of ownership and voting control. The more holding stocks encourage the issuance of new shares as additional funds are needed, because the shareholder voting control is not changed substantially. (6) a minimum credit limit (the company's debt capacity). Managers attempt to adjust the ratio of debt/capital against their desire to achieve the target constrained by attitudes or confidence of the creditors. Creditors establish their confidence variable based on company size, growth potential and business risks, ie: $a$ ) the size of the company, in which large companies can borrow more and in a better limit than smaller companies, $\boldsymbol{b}$ ) the growth of the company's assets are considered as indicators satisfactory to the company's future growth opportunities, $c$ ) stability of income that reflects the company's business risk, $d$ ) asset structure argues that firms with some assets rely on debt financing. (7) The cost of a debt. The greater the cost of debt, the debt becomes less attractive as a source of financing, ceteris paribus. (8) The cost of equity financing. Increase (decrease) in stock prices raises expectations of 'cheap' ('expensive') equity financing and debt becomes more interesting. (9) corporate tax rate. Interest payments are tax can be reduced from the company and this contributed to the interest on debt financing. (10) Inflation expectations. Inflation expectations affect both the demand and credit supply. Inflation expectations will greatly affect the creditors rather than debtors. (11) Availability of loan funds. Funding through debt financing are influenced by government policy. Tight monetary policy making debt financing becomes scarce and expensive. Under these conditions, companies are forced to use more funding with equity, albeit with higher costs. (12) The general rule in the capital market. Investors in the stock market all the time build confidence and habits, there are rigid and flexible.

Manager will decide the financing to fund its business by comparing with other funding sources that may be gained by considering the above factors,. Other funding sources such as external funding is obtained which consists of debt (debt financing) and issue shares (equity financing) as well as internal funding from retained earnings (retained profit). By considering the macroeconomic conditions and business prospects that contain elements of risk and uncertainty, corporate managers will make decisions.

Uncertainty and Risk Business. In an economy that is in a state of uncertain (no certainty) which covers the situation with risk and uncertainty, corporate managers will have difficulty in making a decision to invest. This uncertainty is reflected in the situation where the decision maker does not have enough information to calculate and assign probabilities of revenue that may open a variety of alternative strategies for the company. Meanwhile, the risk of the condition is a situation where the probability of income is known at all costs.

The research model used in this study will look at risk factors under conditions of uncertainty that affect the decision making of corporate managers to make investments. Two types of risk are included in the model are distinguished by their source of business risk (business risk) and financial risk (financial risk).

Business risk arising from uncertainty corporate earnings expectations. This uncertainty arises from possible changes in output prices and input prices, changes in consumer tastes, changes in production methods, and the reaction of (making) a business competitor. In other words, the business risks arising from general business conditions in the economy, the specific conditions of supply and demand in markets where the company's product output and input markets are used for production activities, advances in technology, speed and flexibility in where companies can reduce costs Keita sales are down, and so forth.

Financial risks arising from the use of debt to finance its operations. As debt increases, fixed costs to pay the debt also increased. While shareholders have claimed priority for revenue, the debt to reduce certain alitan net income available to businesses (net of repayments and interest). Furthermore, the use of debt causes the business faced a potential loss of total shares, if the total gross income under Jath fixed cost of debt, i.e., if the company becomes insolvent, a situation where it will be pushed to bankruptcy. Schematically, the various sources 
that cause risks and uncertainties, and business and finance are as follows (Figure 1).

In the economic uncertainty, decision makers do not set the value of income (profitability) of a particular strategy. Each strategy may have some income (depending on the factors discussed in the beginning), each in different levels. If decision makers can determine the probability of income, then faced with the risk.
In this case the decision of 'optimal' will be based on the probability distribution of income earned from each of the strategies and risk attitudes of decision makers. In the end, the investment decisions made by decision makers in companies is the result of consideration of the expected income (return) to be acquired and the total risk to be faced (Figure 2).

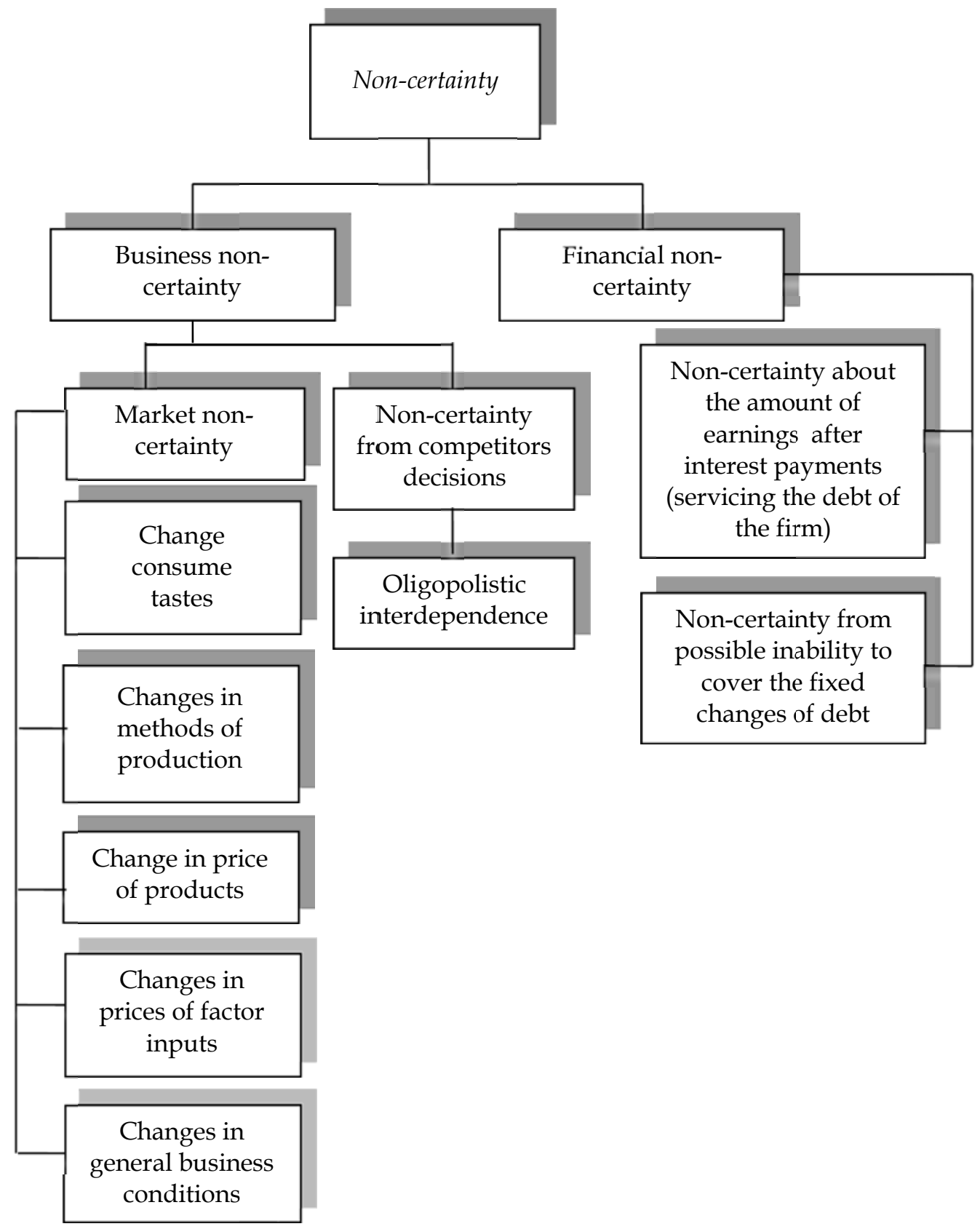

Figure 1. Sources of Uncertainty in the Business (Koutsoyiannis, 1982: 503) 


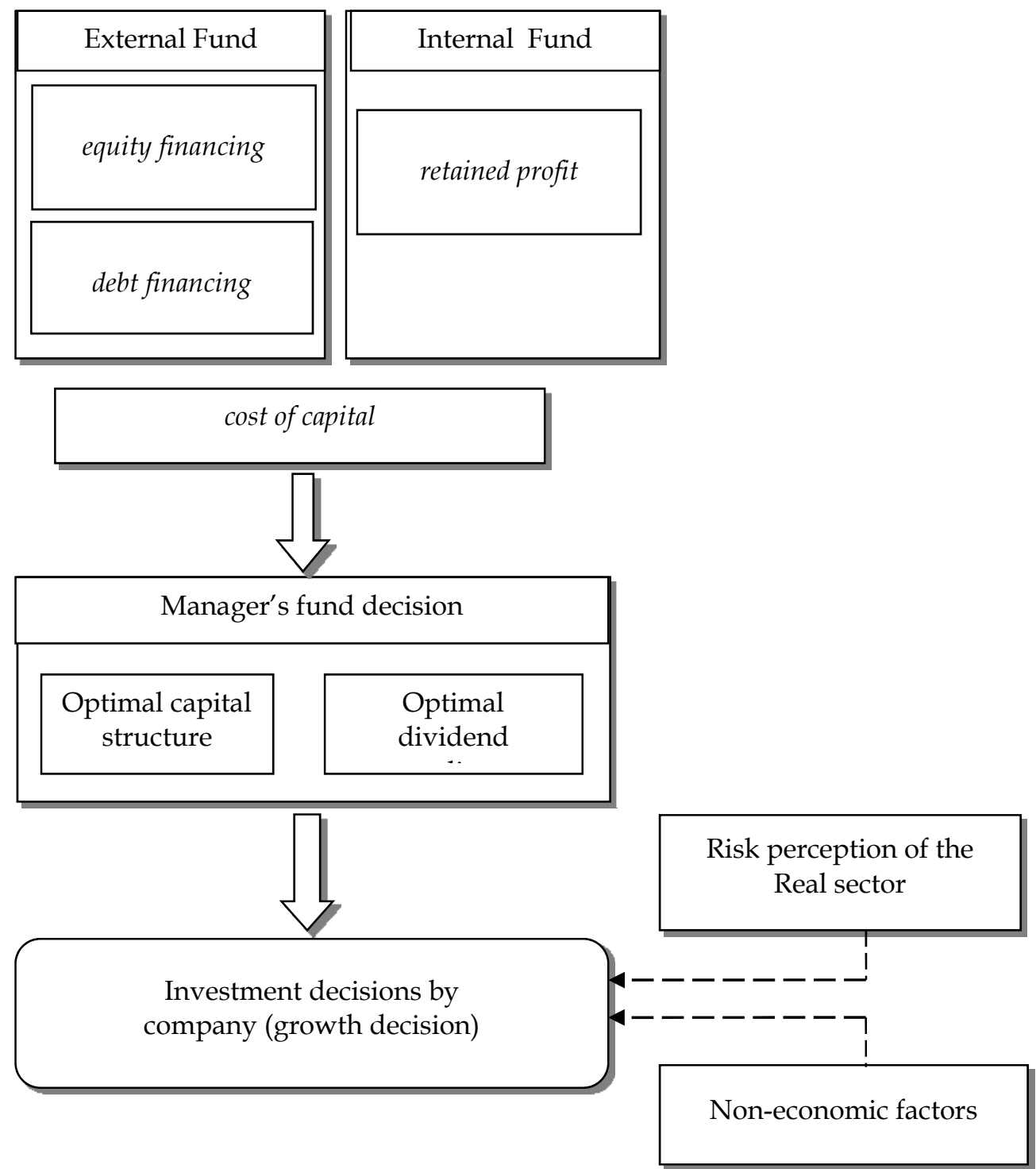

Figure 2. Research Framework

These research questions are as follows: i) whether the decision of the manager in the finance and investment companies are affected by internal factors or external factors the company?; ii) how the behavior of corporate investment decision-making under conditions of risk and uncertainty?.

This study aims to: i) analyze the influence of internal factors and external factors in decision making in finance and investment, ii) analyze the behavior of decision makers in the company's investment risk and uncertainty conditions.

\section{RESEARCH METHOD}

This study covers the real sector in Indonesia, especially small and medium scale enterprises by taking a sample of companies located in Yogyakarta Special Province. To check the availability of one of the main funding source for the company, will do on a survey of some of the bank related to its function as a major financial institution in Indonesia.

\section{Data}

(1) Population. Micro, Small, and Medium Enterprises (MSMEs) in the Province of DIY. Definition of Micro, Small and Medium Enter- 
prises (MSMEs) used in this study refers to the definition issued by Bank Indonesia in PBI No: 7/39/pbi/2005 on the Provision of Technical Assistance in the Development Framework of the Micro, Small and Medium Enterprises. MSMEs classification is as follows: (1) Micro Enterprises: Enterprises that have annual sales of Rp100 million, (2) Small Business: Economic Activity who have a net worth of Rp200 million, excluding land and building of business premises, or has annual sales of Rp1 billion, (3) Medium Enterprises: Enterprises with the criteria of having a net worth greater than Rp200 million up to a maximum of Rp10 billion, excluding land and building of business premises.

(2) Design samples. The samples used in this study is non-probabilistic sampling, i.e. each element in the population does not have the same probability to be sampled (Sekaran, 1992, Cooper \& Emory, 1995; Cooper \& Schindler, 2001). Determination techniques in non-probability sample used in this study was purposive sampling. Purposive sampling method is the basic sample used is considered to conform to some criteria of research to improve the accuracy of the sample (Cooper \& Emory, 1995).

(3) Number of sample: 110 respondents.

(4) Sources of data: (a) Secondary data used in this study is secondary data published by Bank Indonesia (BI) and the Central Bureau of Statistics (BPS), (b) The primary data used in this study were obtained from surveys to small and medium scale enterprises and banks by using questionnaires.

\section{Specifications Model Research}

Determinants of Investment Decision Model and Debt Ratio. Based on the background of the research, the model will include the study of risk factors in the business and financial risks affecting the investment decision. Research model that will be used to look at the factors that influence the investment decision is the recursive model of determinants of investment decisions and the level of debt (leverage). The specifications are as follows:

$$
\begin{aligned}
\mathrm{I}_{\mathrm{i}}= & \alpha_{0}+\alpha_{1} \mathrm{~L}_{\mathrm{i}}+\alpha_{2} \mathrm{AK}_{\mathrm{i}}+\alpha_{3} \mathrm{MI}_{\mathrm{i}}+\alpha_{4} \mathrm{AI}_{\mathrm{i}}+\alpha_{5} \\
& \mathrm{INFE}_{\mathrm{i}}+\alpha_{6} \mathrm{FXE}+\alpha_{7} \mathrm{u}_{\mathrm{i}} \\
\mathrm{L}_{\mathrm{i}}= & \beta_{0}+\beta_{1} \mathrm{AK}_{\mathrm{i}}+\beta_{2} \mathrm{MI}_{\mathrm{i}}+\beta_{3} \mathrm{RL}_{\mathrm{i}}+\beta_{4} \mathrm{RE}_{\mathrm{i}}+\beta_{5} \mathrm{~V}_{\mathrm{i}}(2)
\end{aligned}
$$

Where $I$ is investment, $L$ is Leverage, $M I$ is internal capital, $A I$ is alternative investments, INFE is inflation expectations, FXE is foreign exchange rate expectations, $A K$ is cash flow, $R L$ is lending rate, and $R E$ is regulation of bank credit.

\section{Operational Definition of Variables}

Some of the variables to be used in this study using the definitions and measures as follows:

\begin{tabular}{|c|c|c|c|c|}
\hline Variable & Definition & & Measurement & Hypothesis \\
\hline \multicolumn{5}{|c|}{ Dependent variable: } \\
\hline$I$ & $\begin{array}{l}\text { Investments } \\
\text { decision }\end{array}$ & $:$ & $\begin{array}{l}\text { Dummy Variable: } \\
1=\text { Go to invest } \\
0=\text { Other (not to invest) }\end{array}$ & \\
\hline \multicolumn{5}{|c|}{ Independent variable: } \\
\hline$L$ & Debt leverage. & $:$ & Debt/Total asset & $(+)$ \\
\hline MI & Internal Capital & $:$ & Internal capital/total asset & $(+)$ \\
\hline$A I$ & Other investment. & $:$ & Percentage of fund to other investment & $(-)$ \\
\hline INFE & Exspected inflation. & : & $\begin{array}{l}\text { Dummy variable: } \\
1=\text { increase } \\
0=\text { other (decrease) }\end{array}$ & $(-)$ \\
\hline FXE & $\begin{array}{l}\text { Exspected exchange } \\
\text { rates. }\end{array}$ & $:$ & $\begin{array}{l}\text { Dummy variable: } \\
1=\text { apreciation } \\
0=\text { other (depreciation) }\end{array}$ & $(+)$ \\
\hline$A K$ & Cash flow. & : & $\begin{array}{l}\text { Dummy variable: } \\
1=\text { increasing profit } \\
0=\text { other (decreasing profit) }\end{array}$ & $(+)$ \\
\hline
\end{tabular}
(see Table 1 and Table 2).

Table 1. Determinants of Investment Decisions 
Table 2. Determinant of Leverage

\begin{tabular}{|c|c|c|c|}
\hline Variable & Definition & Measurement & Hypothesis \\
\hline \multicolumn{4}{|c|}{ Dependent variable: } \\
\hline$L$ & Leverage & debt/Total asset & \\
\hline \multicolumn{4}{|c|}{ Independent Variable: } \\
\hline MI & Internal capital. & Internal capital/total asset & $(-)$ \\
\hline$A K$ & Cash flow. & $\begin{array}{l}\text { Dummy variable: } \\
1=\text { increasing profit } \\
0=\text { Other (decreasing profit) }\end{array}$ & $(+)$ \\
\hline$R L$ & $\begin{array}{l}\text { Perception of the } \\
\text { rate of credit } \\
\text { interest. }\end{array}$ & $\begin{array}{l}\text { Dummy variable: } \\
1=\text { High } \\
0=\text { Other (low) }\end{array}$ & $(-)$ \\
\hline$R E$ & $\begin{array}{l}\text { Bank credit } \\
\text { regulation. }\end{array}$ & $\begin{array}{l}\text { Dummy variable: } \\
1=\text { Ease } \\
0=\text { Other (thight) }\end{array}$ & $(+)$ \\
\hline
\end{tabular}

\section{Research Design}

Data obtained from both secondary and primary will be described in advance the characteristics of the respondent (company) at this time. This research conducted a survey method for companies to get the primary data for investment decisions by corporate managers. Analysis of data for testing the hypothesis using econometric and statistical methods in the model specification described in the research model.

\section{Logit Model}

In this section will discuss the analysis of financial risk and business risk by using logit regression analysis. The Reason for using logit regression analysis to estimate the model because the logit analysis can be used to analyze qualitative data that reflect a choice between two alternatives. Logit model is a regression model to quantification relationship between the probability of two choices with some selected characteristics. A probability lies between one and zero. The functional form of the logit model is (Gujarati, 2003:595):

$$
P_{i}=E\left(Y=\mid X_{i}\right)=\frac{1}{1+e^{-\left(\beta_{1}+\beta_{2} X_{i}\right)}}
$$

or can be written as

$$
P_{i}=\frac{1}{1+e^{-Z_{i}}}=\frac{e^{Z}}{1+e^{Z}}
$$

Where $Z_{i}=\beta_{1}+\beta_{2} X_{i}$.
Equation (4) is referred to as cumulative distribution logistic function. $\mathrm{P}(\mathrm{X})$ is the cumulative normal distribution, namely that $P(X)$ is the probability that a random variable with normal distribution, zero mean and unit variance does not exceed $X$.

Logit model makes the probability depends on the observed variables, the independent variable $X_{i}$. Independent variables are multiplied by the coefficient of the variable parameters $X_{i}$, i.e. $b_{i}$. The purpose of this logit model estimation is to find the best value for each coefficient. When a variable coefficient was positive means that the higher value of the variable associated with the low probability that $Y=0$, in other words, the higher the value of a variable means that the higher the probability of $Y=1$.

Logit analysis was used to analyze qualitative data that reflect a choice between two alternatives. In general logit model can be expressed in the following equation (Gujarati, 2003: 596):

$$
\begin{aligned}
\mathrm{L}_{\mathrm{i}} & =\ln \left(\frac{\mathrm{P}_{\mathrm{i}}}{1-\mathrm{P}_{\mathrm{i}}}\right)=\mathrm{Z}_{\mathrm{i}} \\
& =\beta_{1}+\beta_{2} \mathrm{X}_{\mathrm{i}}
\end{aligned}
$$

where $P_{i} /\left(1-P_{i}\right)$ where $P_{i} /\left(1-P_{i}\right)$ is the odds ratio and $L$ is the $\log$ of the odds ratio, $L$ is called the logit, so the model in equation (3) is called the logit model.

The main characteristic of the logit model (Gujarati, 2003:596): (1) $P$ is between 0 and 1, the value is not limited (between $-\infty$ to $\infty$ ), (2) $L$ 
linear in $X$, but the probability is not linear, (3) The coefficient $b_{i}$ measure how far the change of $L$ due to changes in $X$ by one unit.

With features such as the above, then the logit model estimation methods using maximum likelihood estimation method (MLE). Maximum likelihood estimation of a vector valued $\beta_{1}$ parameter vector $\beta_{1}$ MLE that provide the greatest probability of obtaining the data. The coefficient estimates in this way has the characteristics of asymptotic cumulative distribution function like the letter " $S$ ", that is unbiased, consistent, efficient, and normally distributed.

To achieve the goal of research on the analysis of financial risk and business risk and further to determine the impact of leverage on investment decisions in the real sector of the business between the companies that decide to invest and not investing. Category by dividing the company into two groups, it will be seen the influence of various characteristic companies related to investment decisions.

\section{ESTIMATION RESULTS}

\section{Estimation Results of the Research Model}

\section{(1) Financial Risk}

Research model to estimate financial risk analysis by the method of Ordinary Least Square (OLS) is as follows:

$$
\begin{aligned}
\mathrm{L}= & 48.8697263787+4.19931462878^{*} \mathrm{RE}- \\
& (19.49689)^{* * *} \quad(3.072405)^{* * *} \\
& 3.85551220236^{*} \mathrm{RL}+0.539112076794^{*} \mathrm{AK} \\
& (-2.732792)^{* * *} \quad(0.387310) \\
& -0.104351149842^{*} \mathrm{MI} \\
& (-1.727173)^{*}
\end{aligned}
$$

\section{(2) Logit model for Business Risk}

Estimation models for the study of business risk analysis with logit regression method is as follows:

$$
\begin{gathered}
\mathrm{I}=1-@ \text { CLOGISTIC }(-(2.87717350917+ \\
(0.368007) \\
0.141692234338^{*} \mathrm{~L}+ \\
(1.659058)^{*} \\
0.0928556970188^{*} \mathrm{MI}+ \\
(1.542256)
\end{gathered}
$$

$$
\begin{array}{cc}
2.00297033257^{*} \mathrm{AK} & -0.389556538777^{*} \mathrm{AI}- \\
(2.642667)^{* * *} & (-2.387113)^{* *} \\
\left.\left.2.1669370164^{*} \mathrm{INFE}+1.55143447619^{*} \mathrm{FXE}\right)\right) \\
(-1.720473)^{*} & (1.777898)^{*}
\end{array}
$$

\section{Interpretation of Statistics}

(1) Analysis of the estimated regression equation of leverage. The results of estimation of regression analysis for risk analysis for business and financial risks shows that almost all explanatory variables in the equation are statistically significant. In the leverage equation, internal capital (MI), the business sector's perception of the interest rate (RL) and the business sector's perception of bank regulation (RE) has a significant influence. There is only cash flow variable that has no statistically significant effect on leverage.

Business perceptions of bank regulation has a positive influence about 4.19 on investment decisions with a significance level of $1 \%$. This means that if the perception of ease regulation increase with one unit, it will affect the level of debt ratio of $4.19 \%$. While the perception of business agent on credit interest rates have significant negative effects. This means that the higher the perception of bank lending rate, the lower the debt ratio, so that if the perception of rising interest rates increase by one unit will decreased the debt ratio by $3.85 \%$. Internal capital have a negative influence on the debt ratio. If the internal capital rose by one unit will lower the debt ratio by $0.10 \%$.

(2) Analysis of the estimated regression equation of investment decisions. Almost all independent variables have significantly affect on the investment decision in the business sector. Investment decision affect by debt to asset ratio (LF), internal capital (MI) and the perception of the business sector inflation expectations (INFE). While only one variable, namely the internal capital (MI) who have no significant influence on investment decisions.

LR statistics testing the null hypothesis that all slope coefficients except the constants are calculated as zero, indicating a significant probability, which means that all variables simultaneously influence the dependent variable. Meanwhile, McFadden R-Squared indicates that 
the correlation between explanatory variables and the dependent variable only by 0.6 percent. However, the low coefficient of determination is not overlooked in the regression analysis with dichotomous variables (Gujarati, 2003: 607).

(3) Analysis of the estimated regression equation of leverage. The results of estimation on regression for risk analysis in business and financial risks shows that almost all explanatory variables in the equation are statistically significant. In the leverage equation, there is only cash flow variable that has no statistically significant effect on leverage. While other variables those are internal capital (MI), the business sector's perception of the interest rate (RL) and the business sector's perception of bank regulation (RE) have statistically significant influence on leverage.

Business perceptions of bank regulation has a positive influence on investment decisions about 4.19. This means that if the perception of ease regulation rise by one unit, it will affect the level of debt ratio by 4.19 units. While the perception of business agent on credit interest rates have significant negative effects and 1 percent. This means that the higher the perception of bank lending rate, the lower the ratio of debt ratio, so that if the perception of rising interest rates rise by one unit will affect the debt ratio decreased by 3.85 units. Internal capital have a significance negative influence on the debt ratio. If the internal capital rose by one unit will lower the debt ratio by 0.10 unit.

(4) Analysis of the estimated regression equation of investment decisions. In the estimation of investment equation with logit model, almost all the independent variables (Debt to asset ratio variable (LF), internal capital variable (MI) and the perception of the business sector inflation expectations (INFE)) have significantly influence to the investment decision in the business sector. There is only one variable, namely the internal capital (MI) who had no significant influence on investment decisions.

LR statistics testing the null hypothesis that all slope coefficients except the constants are calculated as zero, indicating a significant probability, which means that all variables simultaneously influence the dependent variable.
Meanwhile, McFadden R-Squared indicates that the correlation between explanatory variables and the dependent variable only by 0.6 percent. However, the low coefficient of determination is not overlooked in the regression analysis with dichotomous variables (Gujarati, 2003: 607).

We must transform the logit coefficients back into Odds-Ratio to interpret the regression equation coefficients logit model, which measures the magnitude of the effect of the independent variable changes the dependent variable. The way is to find the antilog of the coefficient estimates, reduce it to 1 , then multiplying by 100 , then we will get the percentage change in the odds of each increase of one unit of the independent variables (Gujarati, 1995, p:559). Another way to interpret the logit regression coefficient is to find the natural $\log e$ to the same exponent of the logit, and the common odds-ratio. By looking at the results of estimation of the model equations above, we know that in fact the probability of investment decisions are influenced by debt ratio, cash flow, an alternative investment, business inflation perceptions and expectations of exchange rate. From the results above the estimated regression equation is known, that there are three variables have a positive influence on investment decisions taken by the businesses i.e. debt ratio, cash flow and exchange rate expectations. While the variable alternative investments and inflation expectations have a negative influence on investment decisions

The results of logit regression estimation found that the debt ratio is significantly positive effect on investment decisions by 0.142 , or by taking the antilog of the slope parameter coefficients of the independent variables, then if the debt ratio increased by one unit then it would raise the probability of investment decisions at 15,22 percent.

Positive cash flow variable affect the probability of investment decisions, where the higher cash flow will further support the investment decision, so that if the cash flow rose by 1 percent, then the probability of investment decisions - by taking the antilog of the coefficient of education obtained by 1.158623 - will rise by $15 \%$. 
The influence of the alternative investment has a negative and significant influence with the probability of making an investment of $67.73 \%$.

While the perception of inflation have a significant and positive influence on investment decisions by 0.147232 , or if the perception of inflation rose by one percent probability it will affect investment decisions by 15.86 percent. Exchange rate expectations businesses have a significant positive effect of 1.551 units of investment decisions or in other words, if the perceptions of the foreign exchange rates increase would raise the probability of making an investment of 71.8 percent.

\section{CONCLUSION}

The analysis estimates the overall regression for the analysis of business risk and financial risk to show that almost all explanatory variables in the equation are statistically significant. In the leverage equation, the variable has no statistically significant effect on leverage variables only the variable cash flow. While other variables are internal capital (MI), the business sector's perception of the interest rate (RL) and the business sector's perception of bank regulation (RE) have a significant effect.

The estimation equation regression model for investment decisions have found that the probability of investment decisions are influenced by debt ratio, cash flow, an alternative investment, inflation perceptions and expectations of exchange rate variables. There are three variables have a positive influence on investment decisions taken by the businesses, i.e. the debt ratio, cash flow and exchange rate expectations. While the alternative investments and inflation expectations have negative significant effects on investment decision.

Implication. Based on the conclusion, there are some suggestion from this research. There is need the ease of bank regulation in relation to lending to the real sector and bank lending rates concessions. in addition, the availability of bank loans with affordable interest rates is also needed real sector. Further, to encourage investment in the real sector, is necessary to create a conducive macroeconomic conditions. Macroeconomic conditions that support the investment decision is includes the stability of the exchange rate and inflation rate.

\section{REFERENCE}

Agung, Juda. 1998. Financial Deregulation and the Bank Lending Channel in Developing Countries: The Case of Indonesia. Journal of Asian Economics. Vol. 12, No. 3.

Agung, Juda. 2000. Financial constraints, firm's investment and channels of monetary policy in Indonesia. Working Paper.

Agung, Juda, Bambang Kusmiarso, Andry Prasmuko, Bambang Pramod, Erwin G Hutapea, Joko Nugroho Prastowo. 2000. Post-Crisis Credit Crunch phenomenon: Facts, Impacts and Policy Implications. Structural Studies Section and Financial Market Development Directorate of Economic Research and Monetary Policy Bank Indonesia.

Akerlof, George A. 1970. The Market for Lemons: Qualitative Uncertainty and the Market Mechanism. Quarterly Journal of Economics 84, August: 488-500.

Alamsyah, Halim, 2004. Banking Disintermediation and Its Implication for Monetary Policy: The Case of Indonesia. Proceedings of an International Seminar Held in Denpasar - Bali, december 2004.

Azis, Iwan Jaya. 2000. The Nonlinear General Equilibrium Impact of the Financial Crisis and the Downfall of Manufacturing. The Developing Economies, XXXVIII-4 (December 2000): 518-46.

Azis, Iwan Jaya and Yuri Mansury. 2004. Measuring Economy-wide Impact of Financial Shock ". ASEAN Economic Bulletin, 20 (2): 112-27.

Bank Indonesia. Annual Report of Bank Indonesia. 1998/1999-2005.

Bank Indonesia, 2006, The Monetary Policy Review, December 2006 
Bank Indonesia, 2006, Development of Selected Indicators of Real Sector, October 2006.

Beck, Thorsten and Ross Levine. 2002. Industry growth and capital allocation: does having a market - or bank - based system matter?. Journal of Financial Economics, (64): 147-180.

Bernanke, Ben S., Mark Gertler and. 1995. Inside the Black Box: The Credit Channel of Monetary Policy Transmission. Journal of Economic Perspectives, Vol. 9 (4): 27-48.

Carpenter, Robert E. 1994. Finance Constraints or Free Cash Flow? The Impact of Asymmetric Information on Investment. Working Paper, Department of Economics, Emory University, Atlanta, January 13.

Cooper, D.R. \& Emory, C.W. 1995. Business Research Methods, Fifth Edition, Chicago: Richard D. Irwin, Inc.

Cooper, D.R. \& Schindler. 2001. Business Research Methods, Seventh Edition, McGraw-Hill International.

Cottarelli, Carlo and Angeliki Kourelis. 1994. Financial Structure, Bank Lending Rates, and the Transmission Mechanism of Monetary Policy. IMF Staff Papers Vol. 41 (4): 587-623.

Diamond, D. W. 1984. Financial intermediation and Delegated Monitoring. Review of Economic Studies, LI :393-414

Diamond, D. W. and P. Dybvig. 1983. Bank Run, Deposit Insurance, and Liquidity. Journal of Political Economy (91): 401-419

Fazzari, S., R.G. Hubbard, and B.C. Petersen. 1988. Financing Constraints and Corporate Investment, Brookings Papers on Economic Activity 1: 141-195.

Ford, J.L., J. Supreme S., S. S. Ahmed, and Bagus Santoso. 2003. Bank Behavior and the Channel of Monetary Policy in Japan, 1965-1999. The Japanese Economic Review, Vol. 54 (3): 275-299

Hermeindito. 2004. Information Asymmetry and Management Control: Sensitivity Analysis Of Investment And Leverage
Funding Sources Selection, Dissertation, unpublished, in the Doctoral Program of Economic Sciences, Gadjah Mada University, Yogyakarta.

Insukindro. 1990. The Short-and Long-Term Determinants of Bank Credit and Money Markets in Indonesia. Unpublished $P h D$ Dissertation, University of Essex.

Jensen, Michael and William Meckling. 1976. Theory of the Firm: Managerial Behavior, Agency Costs and Ownership Structure, Journal of Financial Economics. 3: 350-360

Kim, Hyun E. 1999. Was the Credit Channel a Key Monetary Transmission Mechanism Following the Recent Financial Crisis in the Republic of Korea. Policy Research Working Paper 2103, The World Bank East Asia Pacific Sector Units and Financial Sector Development Unit, April.

Koutsoyiannis, A. 1982. Non-Price Decisions: The Firm in a Modern Context, The Macmillan Press Ltd., Hong Kong.

Maddala, G.S. and Forrest D. Nelson. 1974. Maximum Likelihood Methods for Models of Markets in Disequilibrium, Econometrica, Vol. 42: 1013-30.

Mishkin, Frederic S. 1995. Symposium on the Monetary Transmission Mechanism. Journal of Economic Perspectives - 9( 4): 3-10

Myers, Stewart C. 1977. Determinants of Corporate Borrowing, Journal of Financial Economics, 5: 147-175.

Myers, C. Stewart and Majluf, Nicholas S. 1984. Corporate Financing and Investment Decisions When Firms Have Information that Investors do not Have. Journal of Financial Economics 13: 187-221.

Pramono, Bambang. 2004. Estimating Mechanism of the Credit Crunch and Its Implication to Monetary Policy in Indonesia, Thesis, unpublished, in Master of Arts In International Development at the International University of Japan.

Rhoades, Seza Danisoglu and Z. Nuray Guner. 2003. Economic Uncertainty and Credit 
Crunch: Evidence from an Emerging Market. Emerging Markets Finance and Trade, 39 (4): 5-23.

Rousseau, Peter L., and Paul Wachtel. 1998. Financial intermediation and Economic Performance: Historical Evidence from Five industrialized Countries. Journal of Money, Credit, and Banking. 30 (4): 657-678.

Ferdian, Rully. 2006. 200 Bank in Southeast Asia: Singapore and Malaysia is now Indonesia Market Targeting. InfoBank No. 331, October 2006 Edition: 13-23.

Sangmanee, Amporn. 2004. Banking Disintermediation and Its Implication to Monetary Policy: Thailand's Experience. Proceedings of an International Seminar Held in Denpasar - Bali.

Silber, William L. 1969. Monetary Channels and the Relative Importance of Money Supply and Bank Portfolios. The Journal of Finance, vol.24, no.1.

Saunders, Anthony. 1994. Financial Institution Management: A Modern Perspective. Richard D. Irwin, Inc. USA.

Stiglitz, J.E. and Andrew Weiss. 1981. Credit Rationing in Markets with Imperfect Information. American Economic Review, 71: 393-410

Stiglitz, J.E. 2004. Banking Disintermediation and Its Implications to Monetary Policy.
Keynote Address in Proceedings of an International Seminar Held in Denpasar - Bali.

Stiglitz, J.E., and B. Greenwald. 2003. Towards a New Paradigm in Monetary Economics. Cambridge University Press.

Subramanian, Ramesh and Green, D.J. 2004. Financial intermediation in Asia in Retrospect and Prospect: The Case of Indonesia. Proceedings of an International Seminar Held in Denpasar - Bali.

Takamasa Himada. 2004. Banking Disintermediation and Its Implication for Monetary Policy: Japan's Experience. Proceedings of an International Seminar Held in Denpasar - Bali.

Uy, Marilou J.D. 2004. Financial intermediation and Growth. Proceedings of an International Seminar Held in Denpasar - Bali.

Zulverdy, Doddy, M. Firdaus Muttaqin, and N.J. Prastowo. 2004. Banking and Intermediation Function of undisbursed loan Phenomenon: Causes and Policy Implication. Paper Berkala, Directorate of Economic Research and Monetary Policy Bank Indonesia.

Zulverdy, Doddy, Iman Gunadi, Bambang Pramono. 2005. The Development Bank Portfolio Management Model with Exchange and Factor Loading Factor Conditions of Capital Bank. Working Paper, JEL Classification: G21, C61, E44. 